\title{
The German economy: successes and challenges related to its reforms and the Eurozone*
}

\author{
Josep M. Nadal-Fernández \\ University of Illinois at Chicago
}

\begin{abstract}
This paper is an overview of the development of the German economy since the 1990s. It emphasizes its economic strategy within the Eurozone. The paper lays out an appraisal of the factors that have led Germany to become not only the largest economic power in the Eurozone but also a country whose structural reforms have produced successful results. It also examines how in the face of economic stagnation the increase in German demand would lead to beneficial spillovers for Germany and the rest of the world-especially for the Euro area, whose establishment has greatly contributed to Germany's robust economic growth.
\end{abstract}

Keywords: Germany, economic growth, Euro area, economic stagnation, reforms.

JEL classification: N14, O50.

\section{Resumen}

Este artículo ofrece una visión general del desarrollo de la economía de Alemania desde la década de 1990, haciendo hincapié en su estrategia económica en la zona euro. En este se expone una valoración de los factores que han llevado a Alemania a convertirse no solo en el mayor poder económico en la zona euro, sino también en un país cuyas reformas estructurales han producido resultados exitosos. También se examina cómo ante un estancamiento global, un aumento de la demanda alemana daría lugar a efectos secundarios beneficiosos para Alemania, así como el resto del mundo - especialmente en la zona euro, cuya creación ha contribuido en gran medida al fuerte crecimiento económico de Alemania.

Palabras clave: Alemania, crecimiento económico, eurozona, estancamiento global, reformas. Clasificación JEL: N14, O50.

\section{Introduction}

Germany is one of the most influential economies in the world. In fact, Germany is the biggest country in terms of population $(81,410,000)$ and GDP $(\$ 3.356$ trillion) in the European Union as of 2015 -according to the World Bank-. It is the fourth economy worldwide in terms of GDP and the third global exporter. Its exports (which are almost as high as the USA ones) account for approximately 40 per cent of the total German output and more than 50 per cent of the total EU exports. The German country has managed the financial crisis in Europe better than most of its neighbors - dampening the effects of the enormous stagnation in the EU. As a result,

* I am very thankful to Kelley E. Holcomb and an anonymous evaluator for their valuable insights to improve the quality of this paper. 
the country exhibited an unemployment rate lower than 4 per cent by the end of 2016 -according to the OECD-. Its recent history is full of successes and challenges that have driven the most important economy of Europe into a relevant position in the world.

Indeed, it is a prosperous time for the Germans. Nicholson (2015) analyzes that this economic power has brought a more prominent role for the country in the international arena. The country remains Europe's largest market. As such, Berlin appeared to play a dominant role in the management of the European financial crisis; not to mention its leadership in the security crisis with Russia after annexing Crimea (Telegraph, 2015). It was also decisive in the negotiations with Iran and the USA regarding the former's nuclear program. Chancellor Angela Merkel is regarded as the top-performing democratic leader in the world (Pazzanese, 2014), proving her leadership in facing the refugee crisis. Moreover, its theoretical commitment to renewable energy has set a precedent for the rest of the big countries since it could eventually become the world's first green superpower.

It is necessary to understand some of the recent historical episodes of this country in order to analyze how Germany has attained this predominant economic position. Among the different episodes over the last decades, two of them are especially noteworthy. The first is the process of the German reunification in the 1990s. The country had to deal with the unification of two different economies and its negative aftermath emerged in the early 2000s. In fact, in the 2000s, the Euro project started to be a reality, representing the second episode of these recent events that had a huge influence on the economic situation of the country. Certainly, Germany's strategies for economic growth since the 1990s cannot be understood without the context of the monetary union that the Eurozone represents.

Thus, this paper anatomizes the components of the German strategy from a macroeconomic stance, highlighting its relationship with the European Monetary Union since its creation. The paper continues as follows. Section 2 describes what direction Germany's strategy took to overcome the challenges of the unification and especially the effectiveness of the Hartz labor reforms. Section 3 concentrates on the particular structures of the banking system and oriented policies that support the private sector. Section 4 is an assessment of the indispensable role that the Eurozone played in its first decade to fortify the German economic model. It also examines some of the causes of the Euro crisis and advocates for an increase in Germany's support of ECB as lender of last resort, as well as for a demand expansion by the country. Lastly, section 5 presents a set of conclusions.

\section{Economic strategy and reforms in Germany}

Germany has traditionally exhibited a strict monetary policy. Hyperinflation has been one of its main phobias since the period between WWI and WWII. Along with this inflationary apprehension, the country has tried to use a very orthodox fiscal policy so 
that the country will not suffer anymore from the high debts and deficits that triggered the hyperinflation of the 1920s. However, the country had a huge fiscal expansion to reorganize, recapitalize, and close some businesses and institutions in East Germany after the reunification. As a result, for the first time since WWII, Germany faced a situation where the country ran a public deficit for some years, as shown in Figure 1, with a reduction in its profit margins and a negative current account.

These were the negative economic consequences of the reunification. In this regard, the reunification prompted a property bubble when the government incentivized private and public spending in order to rebuild East Germany. Yet, when the dotcom bubble burst, Germany was hit very hard and the economy lapsed into a worrisome corporate balance sheet recession. This generated a set of initiatives that were intended to reverse the situation, especially since the Euro was already a reality.

The labor market reforms that were undertaken were the pillars of this such a strategy. Under the pressure of an alarming economic situation and the potential competition from other Eurozone members, the German labor unions worked closely with government and business leaders and accepted modest wage increases in exchange of job security. These factors improved Germany's international competitiveness and built the foundations for its economic outperformance. In addition to that, the existence of a single currency, which eliminate some transaction costs, boosted the export model that Germany started to embrace. Export-driven growth has supported a rising number of jobs from thereon.

Most of these measures were carried out under the far-reaching Hartz labor market reforms, which were divided into four phases during 2003-2005. The plan emphasized the productivity of the labor at the expense of higher salaries, but guaranteed more stability over time, especially during negative cycles. Additionally, several options for retirement were eliminated, so that firms and workers were discouraged to arrange consensual retirements for older workers during this recession. Also, part-time jobs were promoted to reduce the labor cost and increase the employment.

\section{FIGURE 1}

GERMAN GOVERNMENT DEFICIT AS PERCENT OF GDP, 1995-2014

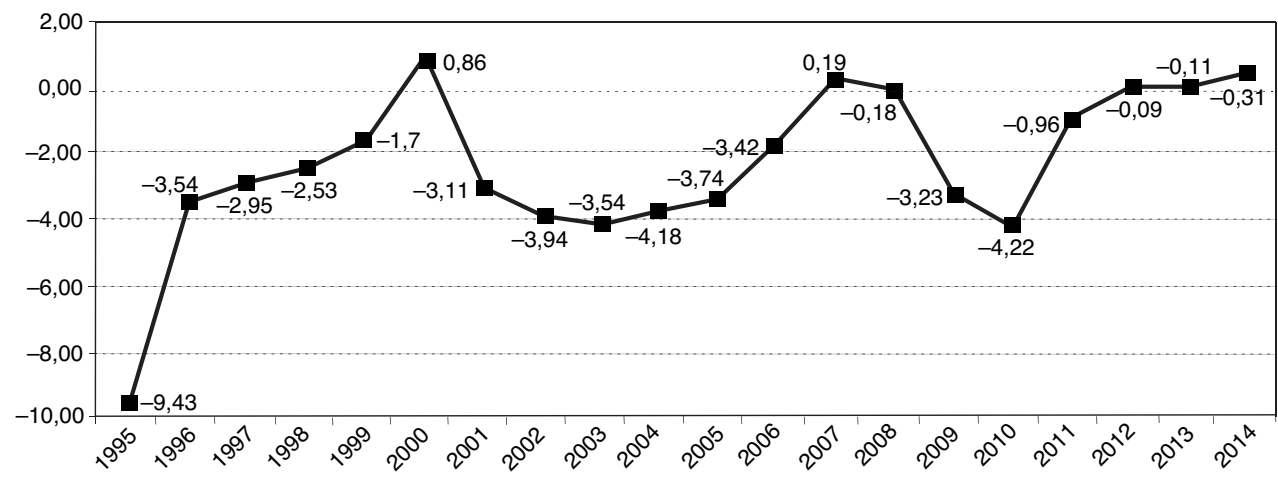

SOURCE: OECD. 
FIGURE 2

TOTAL LABOR FORCE IN THOUSAND PERSONS, 1991-2014

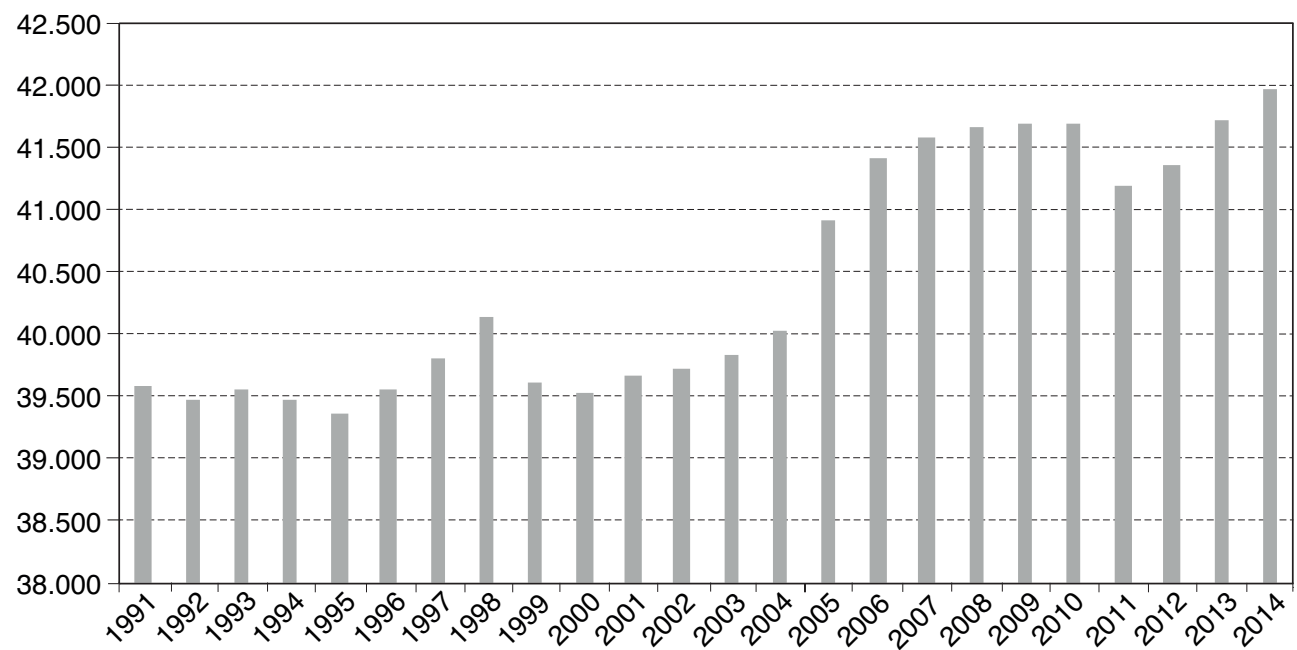

SOURCE: OECD.

That said, cost moderation was never the explicit aim of these reforms (Jacobi and Kluve, 2006). Instead, the reforms were primarily designed to cause a better job matching based on a cooperative process between chambers of commerce and firms. As a matter of fact, the German vocational education is a worldwide example of vocational training, which adequately prepares the labor force that lack higher education. Under closer examination, it can be seen that the system had existed for several decades. Aside from Hartz, there were reforms undertaken in 2005 that contributed to strengthening the worldwide recognition of a German dual training scheme. This produced an effective combination of theory and training embedded in a real-life work environment.

This dual training system should not be confused with the occupational programs that are intended to provide better employment prospects for those unemployed. Regarding the latter, there is a consensus on the literature (Bonin and Schneider, 2006; Jacobi and Kluve, 2006) supporting that the effectiveness of these occupational training programs were improved by in large thanks to the Hartz I reform. Besides, this reform along with Hartz II helped speed up the matching process by including private firms in the process of assisting workers in their search for jobs (Burda and Hunt, 2011; Fahr and Sunde, 2009).

By contrast, Hartz III concentrated its efforts on the reorganization of the federal employment agency and its local employment offices, augmenting the efficiency of employment agencies immediately. Thus, the effects of both reforms became more amplified than the effects of the single reform waves, simply because Hartz III showed a positive effect on the speed of unemployment outflows compared to the 
period after the first wave Hartz I/II. In effect, there is rich literature that empirically quantifies the impact of the reforms on the matching process.

This ample evidence (Klinger and Weber, 2016; Stops, 2015) shows that the reforms had a positive outcome on the labor market, accelerating the outflows from unemployment to employment by 5-10 per cent according to Fahr and Sunde (2009). The improvements in job matching and unemployment spells were especially remarkable in East Germany where unemployment rates were much higher than in the rest of Germany's regions. The reforms also particularly affected certain industries, which were primarily located in East Germany.

In this regard, Möller (2010) observes how the firms that suffered the most in Germany from the world recession also had the most severe recruitment problems before the crisis. These firms were mainly part of the manufacturing sector, with a considerable volume of exports as well as a shortage of a trained workforce. Therefore, the enhancement of the mechanisms to help job search has transcended the labor market and contributed to a more successful realization of companies' activity plans (Stops, 2015) boosting in turn the international competitiveness of German firms.

Beyond Hartz, the government kept implementing reforms to fulfill its labor market goals. Minister Schroeder's «Agenda 2010» reforms reduced safety nets for the unemployed, encouraging people to accept lower-paying jobs. The increasing trend to outsource more production to the new Eastern EU members helped wages to remain low even after the reforms. In fact, part of the literature devoted to labor reforms in Germany points to the reduction in job protection mechanisms as the contributory factor to make the labor market more dynamic.

For instance, Fujita and Gartner (2014) consider it misleading to analyze the improvement in the German market by simply highlighting measures typically associated with the Hartz reforms that have been described. Instead, they assert that the most important part of the reforms was the reduction in unemployment benefits. This reduction lowers the reservation wage of workers. Consequently, they are more likely to accept job offers after the reform than before, when collecting unemployment benefits was more financially advantageous for them.

To comprehend the positive change in the German economy, Dustmann et al. (2014) underscore the importance of the German industrial relations when determining the labor cost under severe economic conditions. Thus, instead of fewer benefits, this cost reduction is explained according to them by the decline in unionization -i.e. a change within the system rather than a change of system-. In order to make their point, they argue that wage restraint has been witnessed since the mid1990s, much earlier than the discussed reforms were put in place. Tellingly, the unionization rates have dropped drastically, so have the number of German workers covered by any kind of union agreement, as Figure 3 reflects. Moreover, this trend has been driven by an increase in opening clauses that has strengthened the role of firm-based works so that union agreements are not reached at an industry level. On top of that, work councils in Germany may gain even greater independence from a union in the event of financial distress endangering the survival of the firm. 
FIGURE 3

TRADE UNION DENSITY IN GERMANY, 1999-2013

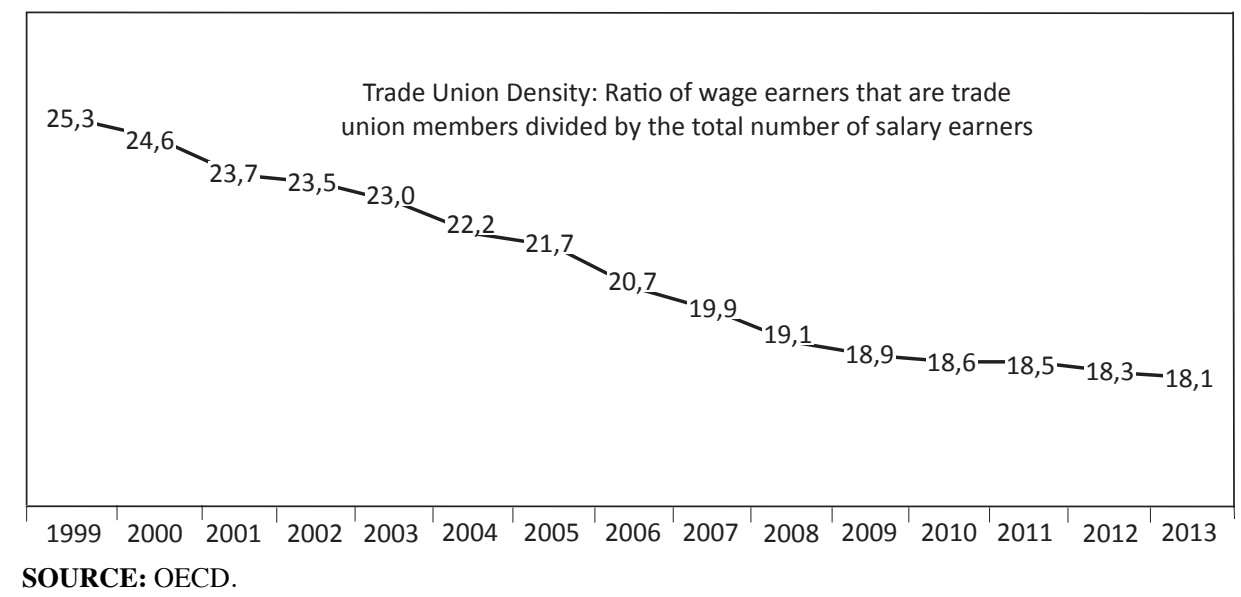

According to Levy's (2012) noteworthy analysis, the low inflation contributed to sustain this labor cost reduction. German inflation was about 1.5 per cent during 2000-2008, persistently below the Eurozone average of about 2.25 per cent and largely maintaining real purchasing power despite the moderation in salaries. This wage restraint was not experienced evenly across the wage distribution but the workers in the lower tail saw their salaries disproportionally declined.

Precisely, the main downside of such a strategy is that poverty risk has increasingly affected employees with relatively low employment protection or limited access to unemployment insurance in Germany. As OECD (2014) points out, the reduction of the safety net has negatively affected this type of employees as well as many part-time and self-employed workers. Compared to other European countries, the incidence of low pay employees is still much higher and still increasing. Plus, youth who have not graduated from upper secondary education face grim lifetime employment prospects and education outcomes continue to depend strongly on socio-economic background.

It is puzzling the degree to which the reduction in unemployment benefits and job protection have aided Germany to muffle the economic downturns. As opposed to Fujita and Gartner (2014), Möller (2010) concludes that the reduction in the level of employment protection of permanent workers against individual dismissal fail to explain why unemployment rates have not exhibited any spike since these reforms were undertaken. In fact, there is a myriad of publications with divergent results that reflect the lack of absolute conclusiveness in empirical terms of the reforms outcome on the German economy.

Anyhow, one of the new challenges that the German economy needs to face is to reform its labor market so that economic growth can be more socially inclusive, 


\section{FIGURE 4}

\section{GERMAN PERCENT INCIDENCE OF LOW PAY DEFINED AS WORKERS} EARNING LESS THAN TWO-THIRDS OF MEDIAN EARNINGS, 2000-2012

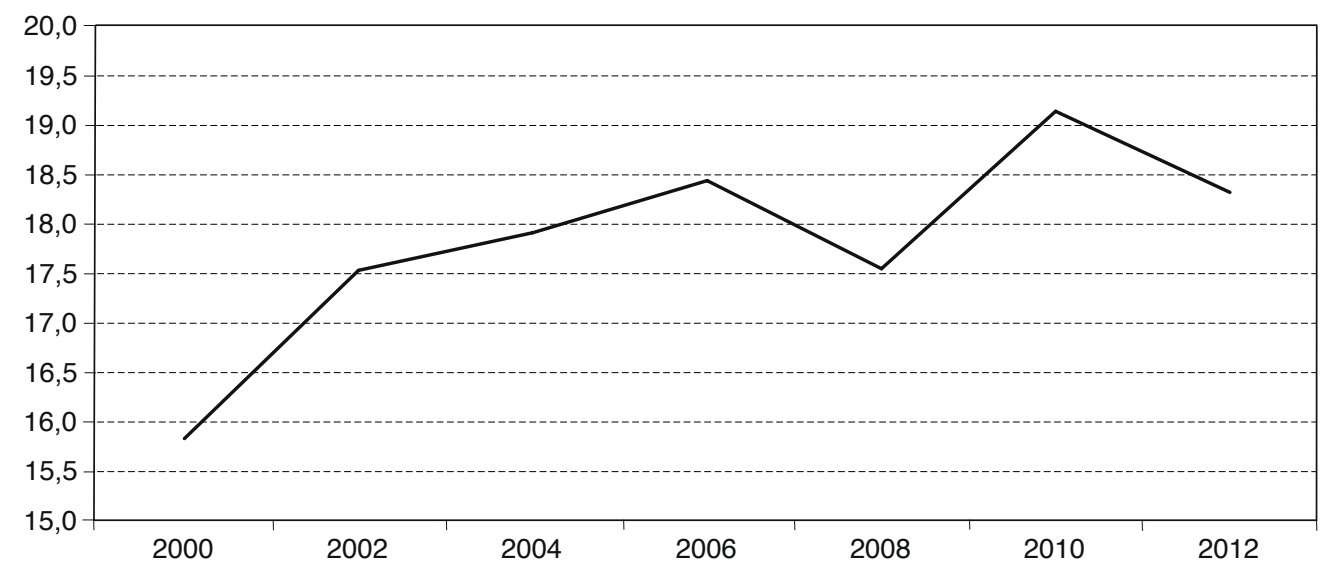

SOURCE: OECD.

reducing disparities in wellbeing. Inequality and relative poverty in Germany have risen since the mid-1990s. Having said that, this phenomenon has taken place in almost all OECD countries. German income inequality has not increased though since 2004 and has remained lower than in most OECD countries. Although collective wage bargaining agreements are still used to set wage floors in several industries, the country set a minimum wage for the first time in 2015. The minimum wage was established at $€ 8.50$. This measure was set by an expert commission, across all economic sectors and promoted by the great coalition of CDU/CSU and SDP that rules the government since 2009. As a matter of fact, Germany tends to reach big coalitions among different agents, not only in the economic field but also in politics.

As the IMF (2014) points out, it is too early to draw conclusions regarding the minimum wage. Besides, it has become a controversial measure and in a different manner than the Hartz reforms. Perhaps, new reforms targeting the gap in employment protection between permanent and temporary workers as well as the worse tax treatment of minijobs towards low-wage workers will take place in the upcoming years. It is clear that this wage stagnation can shed light on the motives of the gigantic current account surplus ( $\$ 287.5$ billion or 7.5 per cent of GDP in 2014). The households' saving-investment gap widened in the early 2000s (IMF, 2014), as the pension reforms and growing income inequality boosted households' savings, residential investment declined by the end of the reunification construction boombeing an explanatory factor of the current account surplus over the last decade. 


\section{Banking structures and specific instruments supporting the private sector}

Another particular feature to take into consideration when describing the economic strategy is the banking industry. Normally, the banking model of Germany is described as a three pillar structure compounded by private commercial banks, public-sector banks, and co-operative banks. In Germany, banks are universal and hold equity from firms. As a result, banks are very influential since they are owners and lenders of businesses as well as custodians of the equity of households, which lowers the direct investment risk of individuals. This structure causes a conflict of interest. On one hand, they gauge the optimal leverage from both perspective creditor and debtor. On the other hand such a structure does not facilitate that small companies will thrive as much as through other banking structures, such as the one in the USA. In other words, German banks are not utterly interested in financially supporting potential competitors since they are also the shareholders of the big companies.

Consequently, Germany is not the most innovative economy in terms of financial markets and industry (Hassan 2014 and IMF 2011). In this sense, another factor that sheds light on the positive German current account is the rising importance of $R \& D$ activities. The difficulty of obtaining external finance to fund R\&D may have led firms to hold more cash. In this particular structure, it is noteworthy to mention that firms have two boards. In addition to the fact that banks are well represented since they own an important portion of the firm's equity. On one of the boards, a third of the members are worker representatives.

In this business environment, small and middle companies known as Mittelstand cohabit with big corporations. Another financial agent known as Landesbanken plays a crucial role to the existence of these businesses. Germany's public banks account for more than 40 per cent (OECD, 2014) of banking sector assets, owned mainly by the local savings banks and the regional Landesbanken. This number is extraordinary large relative to other industrialized economies, Portugal being the second on the list where public banks represent 25 per cent of the total assets (OECD , 2010). The savings banks show sector diversification in terms of the wide range of industries that their portfolios include; but, at the same time, these banks are locally specialized. According to Hakenes et al. (2009), regional banking brings about some tangible benefits, which can be observed in the larger coverage of the population with basic financial services. They argue that it also broadens the access to loan finance for small and medium-sized businesses and more importantly it has encouraged regional economic development in relatively poorly developed regions.

Yet again, this characteristic of the banking sector leads to a conflict of interest; in this case between the public sector and the private sector because sometimes an issue of moral hazard arises. For instance, the state-owned Landesbanken had to receive a significant amount of the rescue package to provide guarantees and recapitalization since it accounted for one-third of all losses derived from the world recession -even though their share of business volume was only 20 per cent (OECD, 2010)-. 
In this regard, one element to take into account in this structure of public banking is that while lower interest rates represent a subsidy benefiting some enterprises, it also entails a reduction in the profit margins of state-owned banks. Thus, some argue (Hassan, 2014) that the spillovers of this mechanism offset the cost to fund stateowned banks, especially in the presence of market failures; whereas some others such as the IMF (2011) consider that these subsidies could be invested in a more beneficial and direct manner.

In general, there is still room for improvement in the German banking industry which was considerably exposed to the world recession. Even though the OECD (2010) quantifies the packaged devoted to the banking sector as 24 per cent of Germany's 2008 GDP, some institutions still exhibit high frailty, especially after the reforms that Basel III has been imposing on banks. According to the IMF (2014), the results of the Basel III quantitative impact study showed that the 42 German banks participating in the exercise complied on average with a fully loaded Basel III common equity tier one capital requirement of 7 per cent as of year-end 2012 . Leverage ratios, however, continue to lag behind. Moreover, German banks show still low operating income. Aggregate net earnings in a IMF sample of 23 banks remained flat in 2013 at $€ 4.8$ billion. They stood at $€ 4$ billion in the smaller group of 10 banks, a small decline relative to 2012.

Despite the weaknesses of its banking industry, Germany demonstrated an impressive ability to overcome the difficulties of the world financial crisis. Once its economic model based on exports was fully implemented, the country made a cooperative effort to dampen the harmful consequences as much as possible. For instance, Dietz, Stops and Walwei (2012) point out a set of subsidies as a way to counterattack the problems that the financial crisis generated. The German government helped the private sector through an already existing short-time working

FIGURE 5

NET INCOME OF GERMAN BANKS IN BILLIONS OF EUROS IN 2013

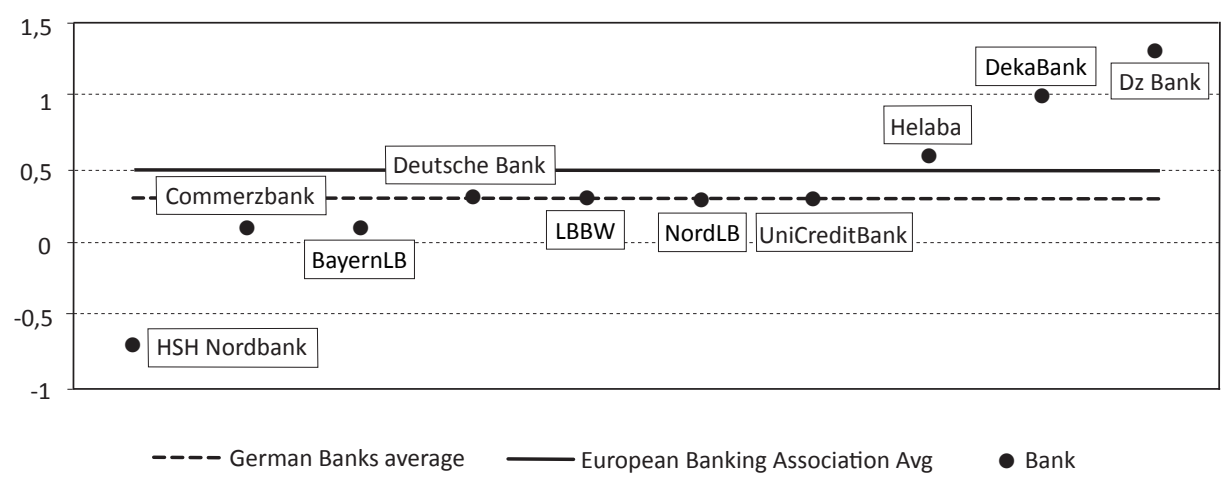

SOURCE: IMF. 
program known as Kurzarbeit. This program consisted of a subsidy for working time reductions where the unemployment insurance partly compensates for workers' income losses and the costs of firms to maintain workers. In particular, this aid offsets 60 per cent to 67 per cent of the forgone earnings and lasts at most six months. Yet, during the crisis, the program was extended by increasing its length -first up to 18 months and then up to 24 months- as well as by further reducing the social security contribution rate.

This measure is designed in such a way that avoids significant layoffs and subsequent economic costs. And more importantly, the labor force can become more productive since these employees undergo training programs in their idle time due to the negative business cycle. Many authors (e.g. Möller, 2010, or Rinne and Zimmermann, 2013) pinpoint short-time program work as a relevant contributor to comprehend how Germany absorbed the shock from the Great Recession without high levels of unemployment. Schneider and Graef (2010) calculate the outcome of the short-time work as the equivalent of about 400,000 jobs in 2009 . However, this amount of jobs only represents 1 per cent of total employment. Moreover, even at the heart of the global crisis the participation in the program was not extraordinary compared to the levels observed in past recessions. For this reason, many authors such as Burda and Hunt (2011) do not consider that this program by itself utterly explains the unexpectedly mild response of employment after the final crash and its aftermath.

In effect, another tool that supports the private sector when facing economic downturns is the adoption of working time account system (Arbeitszeitkonten). This tool allows firms to use overtime without paying for it, as long as hours per worker get reduced at a later time without any cut in salary, so hours end up averaging to standard hours throughout a window of time. When the Great Recession hit the German economy, most workers had accumulated high surpluses of working time accounts. Under this system, if workers are laid off with a surplus in their account, then the employer needs to pay them an overtime premium on top of other costs that it has to bear for the termination of employment. As a result, employers deal with a new tradeoff with a disincentive to lay off. Basically, they can keep workers employed at low hours until the accounts are drawn down to zero and then proceed to fire employees without an overtime premium.

This system of working time accounts was particularly widespread right before the Great Recession compared to previous recessions in Germany. The usage of this system was especially promoted and reinforced by the ruling of the Federal Labor Court (Bundesarbeitsgericht, 2010) in November 2007 where it was concluded that an employer could not lay off a worker if any co-worker doing the same job had a surplus in the account. This reinforcement sheds light on other factors that boosted an adjustment in the labor market along the intensive margin (hours per worker) rather than the extensive margin (layoffs). Indeed, Burda and Hunt (2011) assess that neither short-time working programs nor the effects of the labor reforms described in the previous section can explain 40 per cent of the employment saved in response 
to a drastic drop in output in Germany. Instead, they measure the effect of exhausting working time accounts, translating into a reduction of 0.5 per cent of annual hours. Hence, this measure could be considered to have saved 0.5 per cent of employment in Germany.

All in all, these mechanisms to support the private sector-especially emphasizing the sustainment of employment in the face of economic adversity- have led to a feature very particular to its labor market. That is, most of the reduction in employment is observed in terms of hours per worker rather than losses of jobs. As such, unemployment rates have prevailed in staying quite low since the recession. In fact, Figure 5 shows how the relation between unemployment and hours per worker in the German economy is the opposite of the OECD countries as a whole.

This relationship is measured as the responsiveness of the labor market in terms of hours when unemployment increases. OECD countries exhibit a negative elasticity of 10 per cent while Germany responsiveness is not only more inelastic but even positive, being 5 per cent. Tellingly, the explanation behind the downward sloping trend of the OECD countries is: as unemployment becomes lower, new hires are more scarce, so the only way to keep up with production is by spanning the hours of the already hired labor force. On the other hand, the German upward sloping trend might reflect two characteristics. First, the labor market is less responsive to changes in unemployment. Second, when unemployment is low, not all employees are used at full capacity due to the instruments of the German market such as working time accounts, short-time working programs and the so-called minijobs. In line with Rinne and Zimmermann (2013), one can come to the conclusion that firms follow a sequential approach in using the different instruments at their disposal. Initially, they tend to exhaust working time accounts and then switch to short-time work, adjusting their employment levels almost entirely at the intensive margin.

Though two caveats are worth mentioning. First, the traditional rigidity of the German labor market does not explain this phenomenon since other markets with less flexibility still exhibit a negative elasticity in comparison to the OECD as a whole. For instance, Spain, having a similar fall in GDP and in some aspects a more rigid market, exhibits a very inelastic but still negative slope coefficient. Second, the correlation does not necessarily imply causation and more forces are intertwined to determine the final outcome.

\section{The German economic model within the Eurozone}

The success of the implementation of the German model also has a lot to do with the beginning of the Euro as a single currency in a big area of the EU. In fact, from 2000 to 2008 German exports of total goods and services, including those to other European nations, rose more than 70 per cent. While the German economy was applying austerity to its own economy some of the other Euro members kept increasing the demand counterbalancing the main drawback of austerity: lack of 


\section{FIGURE 6}

\section{ELASTICITY OF HOURS WORKED RELATIVE TO CHANGES IN THE UNEMPLOYMENT RATE, 2000-2015}

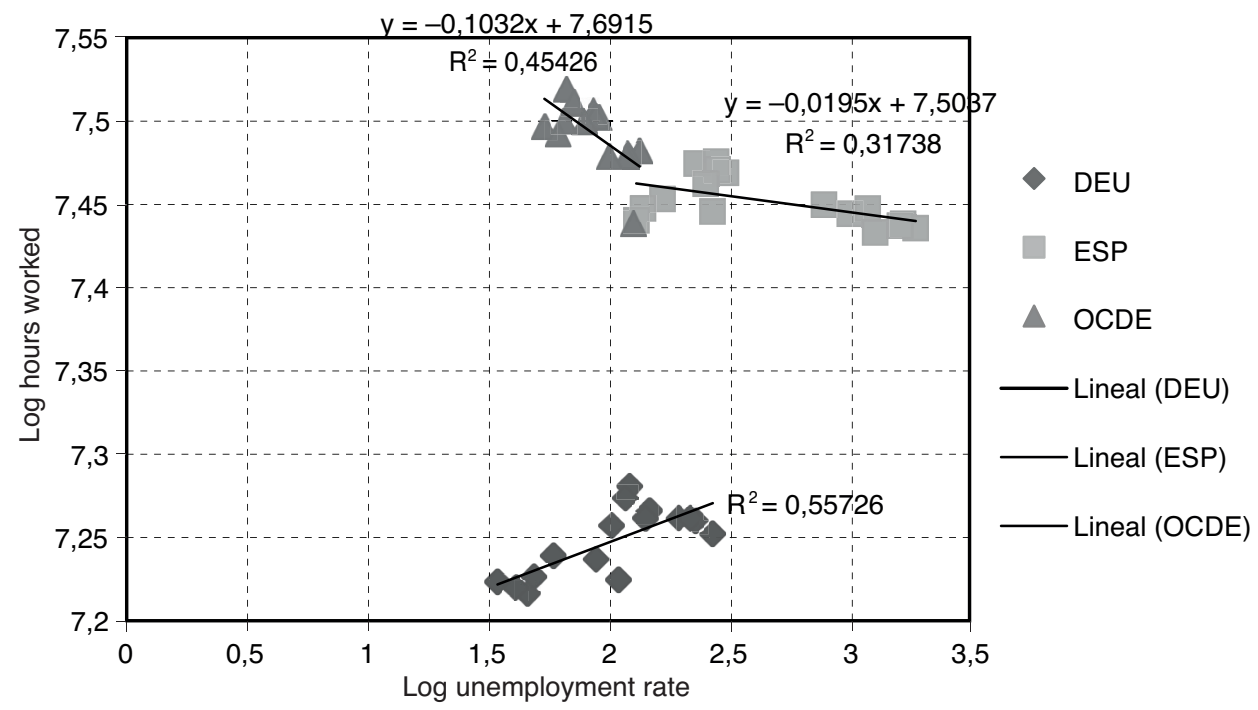

SOURCE: OECD.

internal stimulus to grow. Yet, German exports fell sharply with the global recession. Even so, they are now more than 80 per cent above the levels of 2000 . This high increase is greatly explained by the fact that 60 per cent of Germany's exports go to other European nations, denominated primarily in euros.

As a consequence, since the establishment of the Eurozone, Germany's demand has been rising cumulatively. More recently though, the weak demand from the euro area and a decelerating demand from emerging economies have dwindled this rapid export growth. Domestic demand growth has held up partly because of strong labor market performance, keeping the unemployment level even below its equilibrium rate. Furthermore, the endeavors to make the German market strongly competitive were fruitful because of the inverse tendency of other EU states. Germany's results were magnified due to the divergence in the labor cost trend between Germany and other EU countries. As depicted in Figure 6, while Germany's unit labor costs remained constant during these reforms other EU countries, receivers of most of the German exports, steadily raised their labor costs.

Essentially, the German economy took advantage of the expansive cycle that some of their neighbors were experiencing. What is more, German Chancellor Schroeder pushed strongly to relax the Maastricht Treaty's deficit hurdle after the Germans had already allowed their own debt to overpass the limits that such treaty initially set. Indeed, contrary to some beliefs, France and Germany were the first 
FIGURE 7

UNIT LABOR COST IN SOME OF THE EUROZONE COUNTRIES, 2000-2008 $(2000=1)$

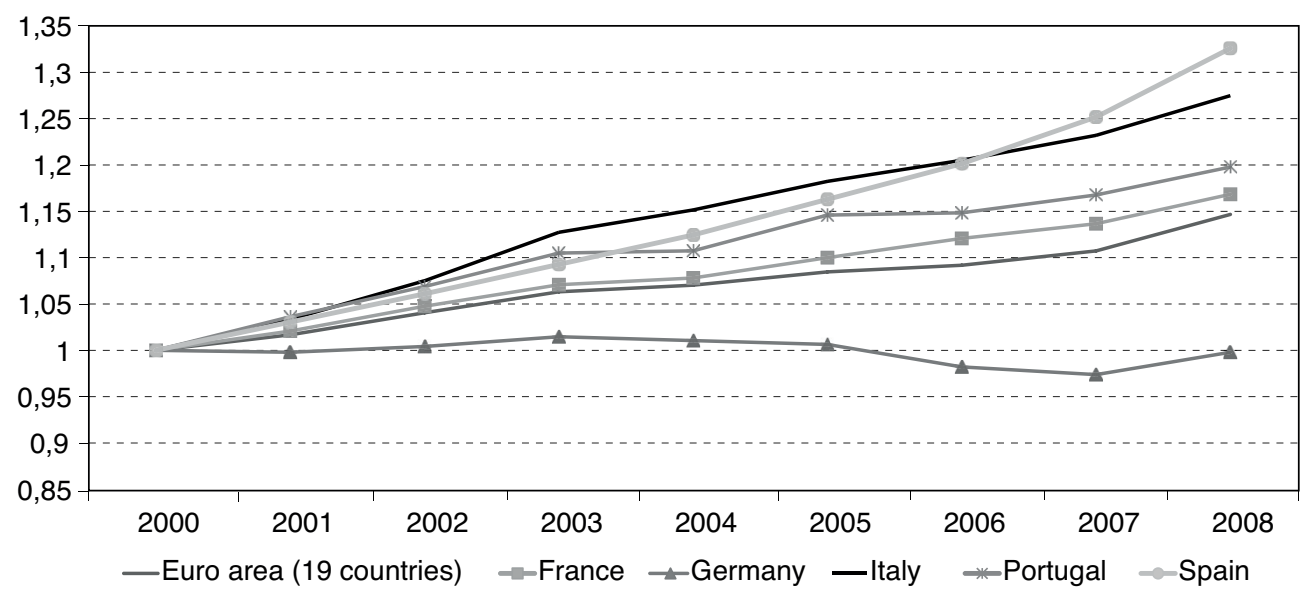

SOURCE: OECD.

countries to violate the guidelines that Maastricht set. As described earlier, the labor hoarding strategy implemented in Germany strongly relied on financial help from the government, whose grossed debt increased by about 40 per cent from 2000 to 2010. Thus, as Figure 7 shows, throughout the reform period in Germany and until the financial crisis, this country is the only one that exceeded the 60 per cent debt threshold, while Spain and Ireland lowered their ratios respectively during that same period.

Additionally, the European Central Bank adopted an expansive monetary policy, increasing the monetary supply and lowering the interest rates. Such an expansive policy during this period facilitated the recovery and consolidation of Germany. However, this policy had a hazardous side effect for peripheral countries such as Spain and Ireland, overheating their economies. That is, given the low interest rate, countries from the periphery borrowed excessively from everywhere, accumulating massive debts and generating bubbles. For instance, Thomson (2013) estimates that more than 40 per cent of the foreign claims in terms of debt on the periphery of Greece, Ireland, Portugal, Italy and Spain were French and German. The banks from the latter were particularly exposed in Spain, Italy and Ireland.

For instance, in Greece there was a huge expansion of external debt in the form of public debt. Deutsche Bank bought Greek bonds. The yields were higher but not particularly higher, but neither were the risks of default, or so it seemed in the expansionary cycle. However, with the hit of the global financial crisis all these national bubbles popped, coming out the imbalances in the financial institutions and public budgets of these countries. Explicitly, Ireland, Portugal and Greece were bailed out by their European peers along with the IMF. 
FIGURE 8

GENERAL GOVERNMENT DEBT AS PERCENT OF GDP, 1998-2008

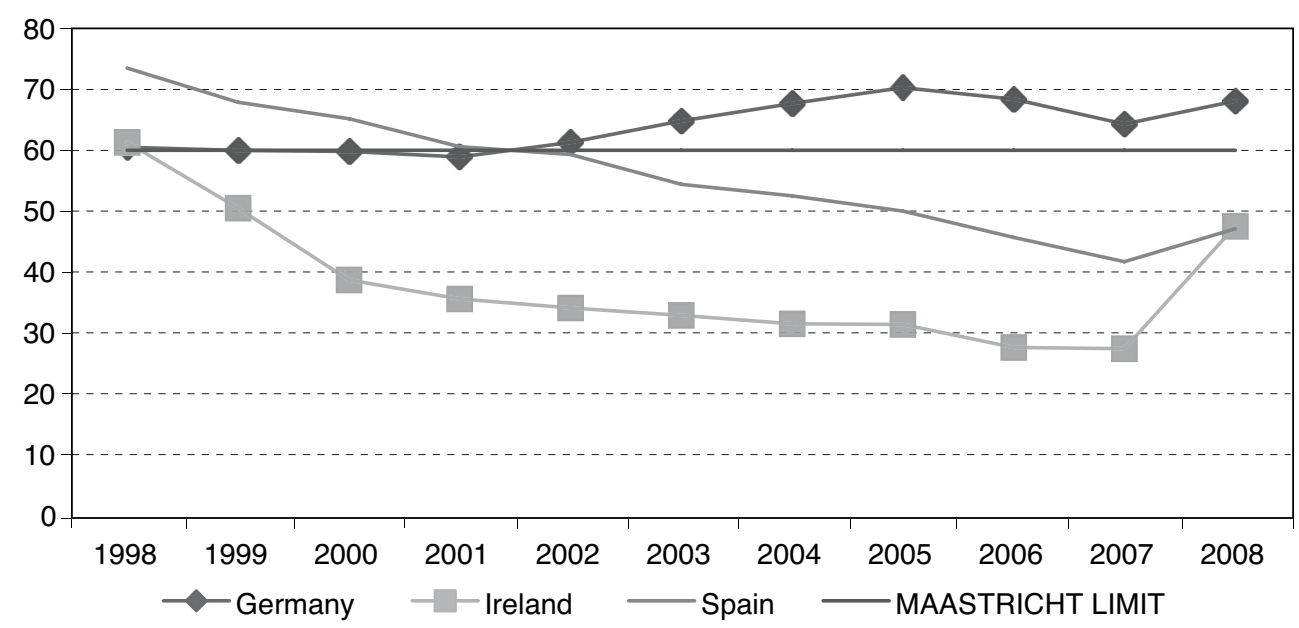

SOURCE: OECD.

According to Lane (2012), «the failure of national governments (from the periphery) to tighten fiscal policy substantially during the 2003-2007 was a missed opportunity, especially during a period in which the private sector was taking on more risk. The credit and housing booms directly generated extra tax revenues, since rising asset prices, high construction activity, and capital inflows revenues, boosted the take from capital gains taxes, asset transaction taxes, and expenditure taxes. Faster-growing euro member countries also had inflation rates above the euro taxes» (p. 54). Nonetheless, some may argue that the German-French alliance that surpassed the limits of Stability and Growth Pact catalyzed this underestimation of sustainable fiscal policies from peripheral countries. The two biggest economies in the Eurozone were not abiding by the rules that were intended to control such aggressive fiscal expansions.

Hence, the successful story of Germany over this period is exacerbated and parallel to the excesses and mistakes of peripheral countries. This is partially due to the measures that pave the path to attain the targeted improvements for Germany. Paradoxically, it seems quite reasonable to assert that Germany could not have achieved this success if the other countries had not increased their spending. For instance, one of the main strengths of Germany during this last decade has been running positive current account balances, the opposite of the other mentioned countries. Yet, as the next figure shows, austerity measures have reversed the negative tendency regarding these countries' current account balances. 


\section{FIGURE 9}

\section{LOANS TO PRIVATE SECTOR FROM DOMESTIC BANKS AND OTHER PRIVATE AS PERCENT OF GDP}

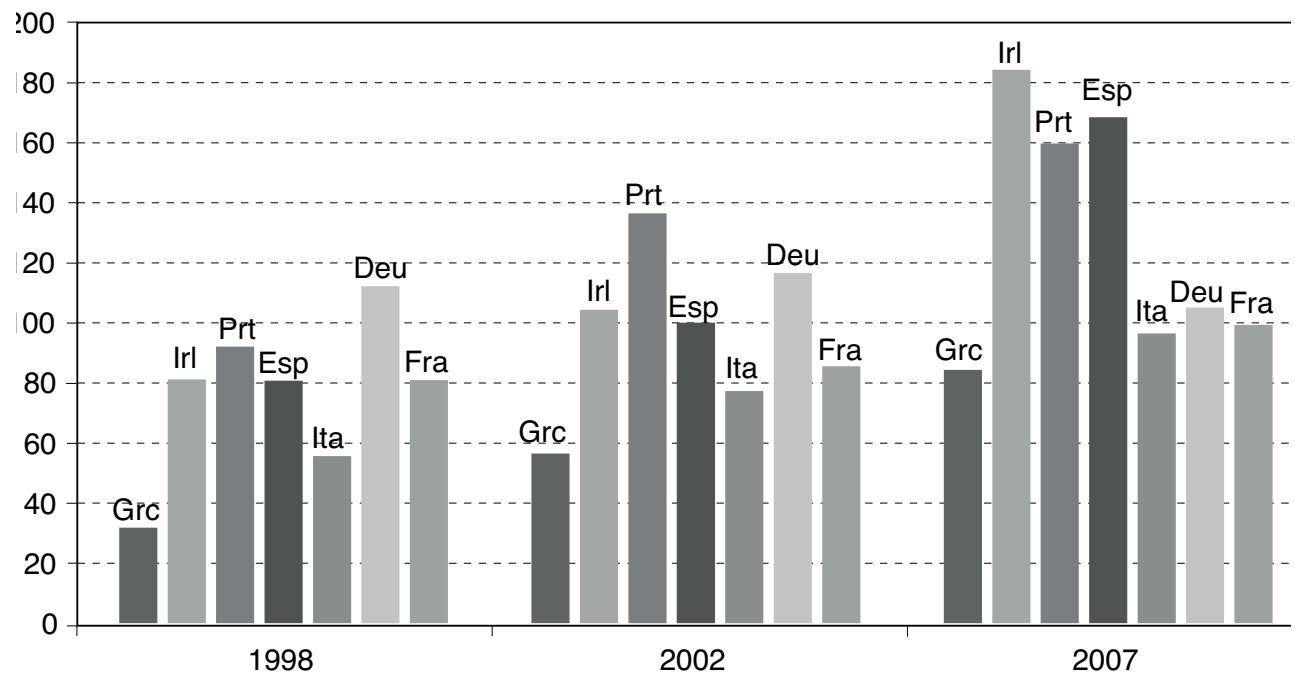

SOURCE: World Bank.

In this regard, the Eurozone during the period previous to the Great Recession functioned in such a way that the surplus that some nations accumulated (e.g. Germany) represented an inflow to their national banks. These banks in turn lent much of it back to the deficit countries, where interest rates were higher due to the lack of savings. This mechanism temporarily sustained some balance across Eurozone countries during the positive business cycle. Banks aggravated this cycle by lending even more to the deficit country, without facing the risk of a potential devaluation of the currency in the context of a monetary union.

Besides, the regulation was set in such a way that permitted German banks to amass effectively unlimited international assets including bonds from the periphery without putting aside capital if those assets were triple A rated. Varoufakis (2016) deems the role of the German banks in this context as a fair-weather surplus recycle. Nonetheless, the question is whether the deficit countries can apply the same recipe as Germany did to reverse the cycle after being shocked by economic slump. And what is more, it is necessary to discuss whether Germany is responsible for helping other Eurozone countries to address their difficulties.

Undoubtedly the first decade of the Euro impacted the German economy positively, bolstering its competitive advantages. Conversely, after the financial crisis, a handful of shortcomings in the design of this monetary union surfaced. Indeed, the original model neglected essential mechanisms to readjust the monetary union when disequilibrium arises. Some may argue that Germany should bear some 
FIGURE 10

CURRENT ACCOUNT BALANCE AS PERCENT OF GDP, 1999-2014

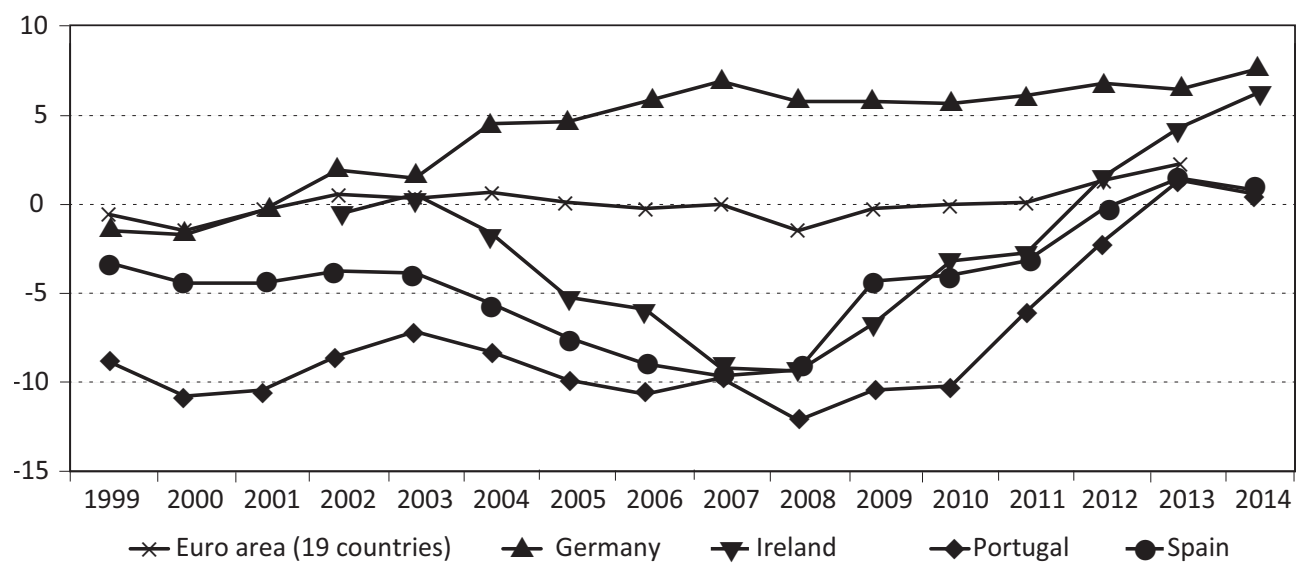

SOURCE: OECD

responsibility for helping to address the difficulties of weaker Euro countries as they might threaten the prevalence of the Eurozone as a whole. According to Kinsella (2013) the problem derives from a monetary union with dissimilar economies between what is regarded as the core countries, led by Germany, and the periphery. This implies that a monetary and fiscal policy mix which benefits the core in general will not benefit the periphery. The debtor nations are also qualitatively different from the creditor nations so they are affected differently by economic shocks.

However, unless the peripheral countries' problems are addressed, the entire Eurozone will grapple with peripheral issues such as a net current account deficit, high and persistent debt to GDP ratios, lower employment levels and lower GDP per capita ratios. Ultimately a non-resolute answer to these challenges will entail lower overall living standards. It is, by large, not desirable for solely core countries to become peripheral; though this may indeed take place, if Germany does not contribute to the growth and alignment of these members. In fact, Kinsella (2013) shows how the shift from peripheral to core (or vice versa) for a single country is a palpable reality. Yet, it should take place gradually with increased momentum by those economies that exhibit stronger growth rates. Ireland, for instance, was a peripheral country in 1990, a member of the core in the early 2000s, and relegated to the periphery again in 2010. Therefore, Germany, as the locomotive of the Euro area and having the firsthand experience of being boosted by others' expansion, should not oppose to the ECB along with the European Commission expansionary measures to stimulate these countries.

For instance, it is very likely that if Germany had not been reluctant to the ECB intervention in growth issues the sovereign debt crisis might have been lighter. The crisis was more a matter of institutional commitment, rather than soaring debts as 
some literature reflects. In this sense, De Grauwe and Ji (2013) show through a set of simple regression analyses the inconsistency of the reasoning that in most peripheral countries the economic recession was originated because of an unbearable debt and not the other way around, which in turn was the seed of the sovereign debt crisis. They particularly show how the change in debt had almost no effect and was statistically meaningless on explaining the spreads in the Eurozone.

Granted that this lack of initial correlation clearly contradicts those who point to the debt/GDP as the root of the crisis, but eventually the increasing cost of the debt might result in an economic burden, creating a self-fulling crisis (Miller and Zhang, 2014). Correspondingly, De Grauwe and Ji (2013) recognize that collective movements of fear and panic can have dramatic effects on spreads. Put differently, the underlying fundamentals as it occurs with bubbles failed to explain the spreads in the Eurozone at that time.

In a similar work, Fuertes, Kalotychou and Saka (2015) econometrically prove how the spreads of exclusively peripheral countries in that period exceeded what the fundamentals could predict. Yet, it is especially illuminating that fundamentals became good predictors again of sovereign spreads for all the Eurozone members after the European Central Bank officially acknowledged its function of lender of last resort launching the Outright Money Transaction (OMT) program. Likewise, De Grauwe and Ji (2013) find that the greater the spreads were before ECB's announcement, the more they diminished after it.

Consequently, these findings underscore how the spreads can be driven by panic movements in the market unless the ECB provides liquidity in this scenario. What is more, it makes a case for the relevant role of the ECB in stabilizing the Eurozone by committing itself to the support of national debt and mitigating fears of the trustworthiness of the Eurozone. Yet, in February 2014, amid fears of contagious effects and loss of sovereignty, the German Federal Constitutional Court declared the OMT to be inconsistent with EU law, albeit being this an instrumental game changer when the bonds of peripheral Eurozone members were under siege.

Taking aside the legislative component, it seems unreasonable to stand on such a rigid position even for Germany along with its orthodoxy. If the country does not see this monetary union as a zero-sum game, supporting the active role of the ECB is the best manner to ensure the continuity of the project. Even from a greedier stance, a ECB's less active role would threaten the Eurozone stability and subsequently the taxpayers in Germany, not to mention the benefits of the single currency for the country. In this sense, not only does the country share a fixed exchange rate with its Euro peers, but also this exchange rate would be much higher for Germany hurting its export model should the euro disappear as a common currency (Tilford, 2010).

Aside from that, the German economy has benefited from a change in the ECB usual operations towards a more $a d$ hoc and proactive role. Specifically, German banks with a high exposure to the periphery were able to repatriate 50 per cent of these invested funds (Thompson, 2013) so that they could be allocated somewhere other than the periphery between the third quarter of 2009 and the fourth quarter of 
FIGURE 11

INTEREST RATES OF GOVERNMENT BONDS MATURING IN 10 YEARS, 2009-2014

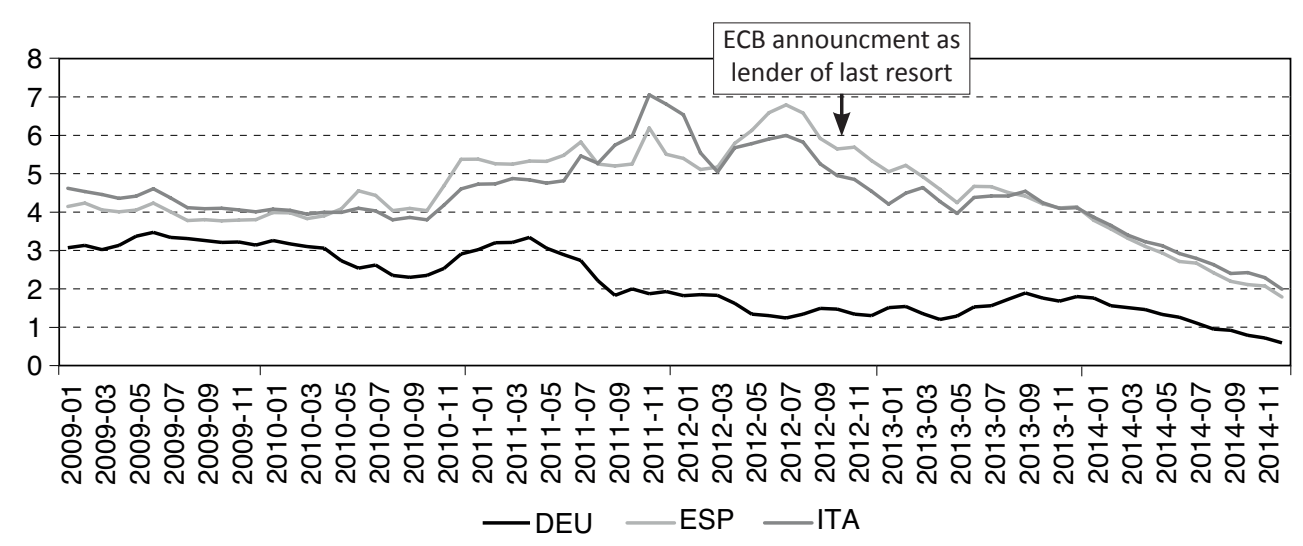

SOURCE: OECD.

2012. This could not have been possible without the ECB's LongTerm Financing Operation (LTFO).

Nonetheless, the function of Germany should not only be limited to supporting ECB's active role, but also to stimulating the economy by increasing its demand given the size of its current account surplus. This would not only have a positive impact on the EU countries to avoid a new turmoil, but also on the entire globe given the importance of the country. Notice though, this suggestion is not at the expense of Germany but for its own sake too, according to the IMF (2014). In other words, such an option would represent a win-win scenario, where all parties would profit from it. In this sense, Germany can afford to undertake certain policies that its economy needs. These polices are also associated with positive spillovers, which, for instance, could support activity across the Euro area. Motivated by more and more urgent infrastructure needs, IMF (2014) simulations suggest that higher public investment would stimulate domestic demand in the near term, while also raising German output over the longer term and would decrease the current account surplus. Hence, they are in Germany's best interest.

Above all, reforms to improve infrastructures, the service industry productivity, and environmental innovation are the key points. The current low-interest rate environment presents a window of opportunity to finance higher investment at historically favorable rates. For instance, implementing reforms in the nontraded service sector would also durably increase Germany's GDP and productivity. One of the OECD (2014) recommendations refers precisely to the environmental aspect. Some sort of tax reform can phase out tax expenditures for activities that damage the environment without harming international competitiveness, and better 
align environmental taxation with negative externalities, by investing in energy independence through sustainable initiatives.

Thereby, higher energy sector investment in Germany would boost growth, facilitate rebalancing, and generate positive spillovers. According to the IMF (2014), the beneficial spillovers associated with higher German public investment can be meaningful, while those associated with public consumption are limited. That is, when comparing the two types of stimuli, it also seems clear that higher Germany's public investment has greater growth spillovers than higher public consumption. Moreover, the domestic impact of higher Germany's public investment and the correspondent spillovers are even larger in the current context as long as the ECB policy remains accommodative. Even with implementation delays due to political processes, regional spillovers are appreciable with the current expansionary monetary policy. The simulations from the IMF (2014) should encourage the German economy to execute these reforms since they are assuredly beneficial for their own country and the rest of the Euro area members as well.

\section{Conclusions}

The set of reforms that Germany has undertaken since the 2000 s, especially in the labor market, have contributed to achieve a very competitive economy, which is extremely oriented to exports. The reforms have brought about some mechanisms such as wage moderation, a better matching process, a short-time program and working time accounts that turned out to be very supportive for the private sector when dealing with economic distress and adjustments in the labor force. These measures fixed the costs associated with the reunification process in the country. Yet, this strategy required a considerable amount of public spending, raising its debt in the short term. Eventually, Germany's debt stabilized because the spending was used in a preventive way to stabilize the labor market rather than as a remedial measure.

Simultaneously, the positive effects of the chosen strategy were magnified thanks to the advent of the Euro as a single currency of a new monetary union. The ECB expansionary polices along with the increasing demand from peripheral countries amplified the effects of such policies on the German industry. The monetary union further strengthened the German export model due to the relinquishment of the devaluation resource and a permanent fixed exchange rate regardless of the difference in balances across countries. Precisely, the divergence between Germany and the peripheral countries has generated a greater burden on the latter after the financial crisis. In this regard, the last events have proved that an active role from the ECB is necessary to avoid a new turmoil in the Eurozone as a whole.

However, financial support from the ECB and other governmental institutions are temporary bridge loans that do not address the problems. The example of Germany might pave the path to carry out this type of necessary structural reforms by the Eurozone countries that are suffering the most from the economic recession and its anemic recovery. In this sense, there is room for Germany to contribute to the 
end of the stagnation given the size of its current account surplus and the monetary accommodative policies in the Eurozone. The increase in German demand would lead to beneficial spillovers not only in Germany (where pressing reforms are necessary) but also in the rest of the world, especially in the Euro area.

By doing so, Germany's increasing demand would notably stimulate peripheral countries. This effect would be similar to the stimulus that Germany received from increase in demand in peripheral countries during the 2000s, when Germany was still consolidating its reformed model. At the same time, this is a necessary but not a sufficient condition since peripheral countries need to keep adjusting their economies so that they eventually get more aligned and closer to the core countries of this monetary union. Achieving such an economic integration could be the new episode of a successful unification for Germany.

\section{References}

[1] BONIN, H. and SCHNIDER, H. (2006). «Wirksamkeit der Förderung der Beruflichen Weiterbildung nach den Hartz-Reformen», IZA Discussion Paper No. 2069.

[2] BUNDESARBEITSGERICHT (2007). «Urteil vom 8.11.2007, 2 AZR 418/06 Betriebsbedingte Kündigung aus Witterungsgründen». Retrieved on September 20, 2016 from http://lexetius.com/2007,4121.

[3] BURDA, M. C. and HUNT, J. (2011). «What explains the German labor market miracle in the Great Recession?». Brookings Papers on Economic Activity, p. 273-319.

[4] DE GRAUWE, P. and JI, Y. (2013). «Panic-driven austerity in the Eurozone and its implications». VOX: CEPR's Policy Portal. Retrieved on February 18, 2016 from http:// voxeu.org/article/panic-driven-austerity-eurozone-and-its-implications .

[5] DIETZ, M.; STOPS, M. and WALWEI, U. (April 01, 2012). «Securing Jobs in Times of Recession». The German Experience during the Financial Crisis 2008/2009. Estudios de Economía Aplicada, 30, 1.

[6] DUSTMANN, C.; FITZENBERGER, B.; SCHÖNBERG, U. and SPITZ-OENER, A. (2014): «From Sick Man of Europe to Economic Superstar: Germany's Resurgent Economy». Journal of Economic Perspectives, 28 (1), 167-188.

[7] FAHR, R. and SUNDE, U. (2009). «Did the Hartz reforms speed-up the matching process?: A macroevaluation using empirical matching functions». German Economic Review, 10, 3, 284-316.

[8] FUERTES, A.; KALOTYCHOU, E. and SAKA, O. (2015). «How did the ECB save the Eurozone without spending a single euro?». VOX: CEPR's Policy Portal. Retrieved on February 18, 2016, from http://www.voxeu.org/article/how-did-ecb-save-eurozonewithout-spending-single-euro.

[9] FUJITA, S. and GARTNER, H. (2014). «A closer look at the German labor market 'miracle'». Business Review (Federal Reserve Bank of Philadelphia), 97 (4), 16.

[10] HAKENES, H.; SCHMIDT, R. H. and XIE, R. (2009). «Public Banks and Regional Development». Journal of Financial Services Research.

[11] HASSAN, F. (2014). «A View From Germany I - How the three-pillared German Banking System has gotten through the crisis». Retrieved on August 30, 2016 from http://www.finance-watch.org/hot-topics/blog/851-view-from-germany-1. 
[12] IMF (July, 2014). Germany Selected Issues. International Monetary Fund, Washington D.C.

[13] JACOBI,L.and KLUVE, J. (2006). «Before and After the Hartz Reforms: The Performance of Active Labour Market Policy in Germany». IZA Discussion Paper No. 2100.

[14] KINSELLA, S. (2013). «Conventions and the European periphery». Social Science Research Network. Retrieved on May 17, 2016 from http://ssrn.com/abstract=2155577.

[15] KLINGER, S. and WEBER, E. (2016). «Decomposing beveridge curve dynamics by correlated unobserved components». In Annual Conference 2014 (Hamburg): Evidencebased Economic Policy (No. 100499). Verein für Socialpolitik/German Economic Association.

[15] LANE, P. R. (2012). «The European Sovereign Debt Crisis». The Journal of Economic Perspectives, 26 (3), 49-68.

[16] LEVY, M. (2012). «Diverging competitiveness among EU nations: Constraining wages is the key». VOX: CEPR's Policy Portal. Retrieved on June 14, 2015, from http://www. voxeu.org/article/how-restore-competitiveness-eu.

[17] MILLER, M. and ZHANG, L. (2014). «Saving the euro: self-fulfilling crisis and the 'Draghi put'». VOX: CEPR's Policy Portal. Retrieved on May 17, 2016 from http:// voxeu.org/article/self-fulfilling-eurozone-debt-crises-and-draghi-put.

[18] MÖLLER, J. (2010). «The German labor market response in the world recession demystifying a miracle». Zeitschrift für ArbeitsmarktForschung, 42 (4), 325-336.

[19] NICHOLSON, P. (2015). «The Myth of a Mighty Germany». Foreign Affairs. Retrieved on June 14 from https://www.foreignaffairs.com/articles/germany/2015-06-01/mythmighty-germany.

[20] OECD (2010). The banking system: Lessons from the financial crisis. Organisation for Economic Co-operation and Development, Paris.

[21] OECD (2014). OECD Economic Surveys: Germany 2014. Organisation for Economic Co-operation and Development, Paris.

[22] PAZZANESE, C. (2014). «Grading 10 top world leaders». Harvard Gazette. Retrieved on August 30, 2016 from http://news.harvard.edu/gazette/story/2014/12/grading-10top-world-leaders/.

[23] RINNE, U. and ZIMMERMANN, K. F. (2013). «Is Germany the north star of labor market policy?». IMF Economic Review, 61 (4), 702-729.

[24] SCHNEIDER, S. and GRAEF, B. (2010). «Germany's Jobs Miracle: Short-Time Work, Flexible Labour Contracts and Healthy Companies». Deutsche Bank Research Briefing. Frankfurt: Deutsche Bank.

[25] STOPS, M. (2016). «Revisiting German labour market reform effects-A panel data analysis for occupational labour markets». IZA Journal of European Labor Studies, 5 (14), 43.

[26] TELEGRAPH (2015). «Minsk agreement on Ukraine crisis: full text in English». Telegraph. Retrieved on August 30, 2016 from http://www.telegraph.co.uk/news/ worldnews/europe/ukraine/11408266/Minsk-agreement-on-Ukraine-crisis-text-in-full. html.

[27] THOMPSON, H. (2013). «The dirty little secret of the euro zone crisis: the German banks». Sheffield Political Economy Research Institute. Retrieved on September 20, 2016 from http://speri.dept.shef.ac.uk/2013/11/11/dirty-secret-euro-zone-crisisgerman-banks/. 
[28] TILDFORD, S. (2010). «Germany’s Euro Advantage». The New York Times. Retrieved on September 18, 2016 from http://www.nytimes.com/2010/07/14/opinion/14ihtedtilford.html?_r=0.

[29] VAROUFAKIS, Y. (2016). And the weak suffer what they must?: Europe's crisis and America's economic future. New York: Nation Books. 